\title{
THE INFLUENCE OF STAND COMPOSITION ON THE MORTALITY OF VARIOUS CONIFERS, CAUSED BY DEFOLIATION BY THE WESTERN HEMLOCK LOOPER ON VANCOUVER ISLAND, BRITISH COLUMBIA'
}

\author{
By J. M. KINGHORN ${ }^{2}$
}

As a student assistant at the Forest Insect Laboratory at Victoria, J. M. Kinghorn commenced hemlock looper mortality and deterioration studies in 1946. Following graduation from the University of British Columbia in 1949 with the degree of B.S.F., he continued with post graduate work at Duke University where he received the M.F. degree in Forest Entomology in 1950. From then up to the present he has been engaged in research on ambrosia and bark beetle problems in British Columbia.

\section{ABSTRACT}

Western hemlock looper outbreaks periodically occur in British Columbia. A guide for estimating losses that accrue from looper feeding has not been available in the past. This report describes the influence of various tree and stand characteristics on the mortality of forests damaged during the last looper outbreak from 1944 to 1946.

Tree death commenced one year following the collapse of the outbreak and continued for another three years. The cumulative mortality up to 1950 was taken as the total loss directly attributable to the insect damage. Tabular analyses of this mortality total with various factors showed that percentage defoliation and tree size were most consistently associated with tree death. Three major forest types were recognized. The basal area mortality of the types was related to the pre-outbreak basal area and to defoliation by multiple linear regression. These analyses arrived at parameters on which future damage surveys in similar forest types can be based.

\section{INTRODUCTION}

Outbreaks of the western hemlock looper, Lambdina fiscellaria lugubrosa (Hist.) have occurred periodically throughout the Pacific Northwest. There is every reason to believe that these infestations will recur. Since tree mortality continues for several years following the cessation of an outbreak, the purpose of this study is to relate total mortality to forest composition and intensity of hemlock looper defoliation, so that ultimate losses can be estimated as soon as damage is inflicted.

The field work was confined to the outbreak that commenced in 1944 and collapsed in 1946 in the region that extends from the San Juan River to Alberni Inlet, and from the west coast to a more or less central divide of southern Vancouver Island. In 1947, after the outbreak had subsided, it was necessary

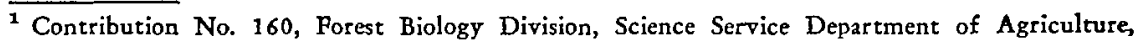
Ottawa, Canada. A revision and condensation of a thesis submitted to Duke University in 1950 , in partial fulfilment of the requirements for the degree of Master of Forestry. Forest Biology Laboratory, Victoria, B.C.
}

Submitted for publication June 30, 1954. 
to determine the amount of timber that would eventually die from the looper feeding of the preceding years. Approximately one and one-half billion board feet of high quality timber on fifty thousand acres was partially or completely defoliated. Because a suitable guide such as the relationship of mortality to percentage defoliation was not available to form the basis of a survey, subsequent estimates of volume losses were uncertain and unsatisfactory. It can now be stated that total mortality approximated one-half billion board feet on fifteen thousand acres. Once salvage decisions have been reached, an estimate such as this has little value. The results of this paper should form the basis for future damage surveys in order to circumvent this difficulty.

\section{Regional Characteristics}

The southwestern portion of Vancouver Island affected by the hemlock looper during the 1944 to 1946 period has a temperate maritime climate. The rainfall varies from 80 to 120 inches per annum, of which about 8 per cent falls during June, July and August. Temperatures are moderate with few extremes occurring in either summer or winter. The records from the nearest weather station at Pachena Point show a January mean temperature of $40^{\circ} \mathrm{F}$. and an Augurst mean of $56^{\circ} \mathrm{F}$.

The region is known locally as the fog-belt because of the heavy blanketing of the coastal fringe with summer advection fog. During fine weather, the fog forms along the west coast of the island; frequently the evening sea breeze carries the fog onshore where it pockets in the valley bottoms. Usually it does not clear in the valleys until late morning or early afternoon. The low incidence of forest fires, and the predominance of tolerant hemlock and cedar forest types is credited to this protective fog blanket.

Since heavy hemlock looper populations rarely occurred higher than about 500 feet above the valley floors, the following discussion of forest types is limited to those at low elevations, and to those areas in which the study was undertaken. The six study areas represent the principal drainages affected by the outbreak. These drainages are Wilson Creek, upper Caycuse, lower Nitinat, Klanawa, Pachena, and Sarita Rivers (Figure 1).

The predominant forest cover throughout all areas is western hemlock, Tsuga heterophylla (Raf.) Sarg. The major associates are Douglas fir, PseudoIsuga taxifolia (Poir.) Britt., and amabilis fir, Abies amabilis (Dougl.) Forbes. The minor associates are western red cedar, Thuja plicata Donn, and western white pine, Pinus monticola Dougl. Sitka spruce, Picea sitchensis (Bong.) Carr., occurs in admixture with the other species on moist sites but is found more commonly in pure and mixed stands that fringe the river banks. Red alder Alnus rubra Bong., and broadleaf maple, Acer macrophyllum Pursh, are the principal deciduous associates. They too, occur only on moist sites along stream banks.

The majority of these stands are mature to over-mature. Heartrot is common, and brooming caused by the dwarf mistletoe, Arceuthobium campylopodum f. tsugensis (Rosend.) Gill, is prevalent on hemlock. Hemlock or, less frequently, amabilis fir predominates in the understory. The less tolerant Douglas fir and spruce regeneration is almost non-existent. 


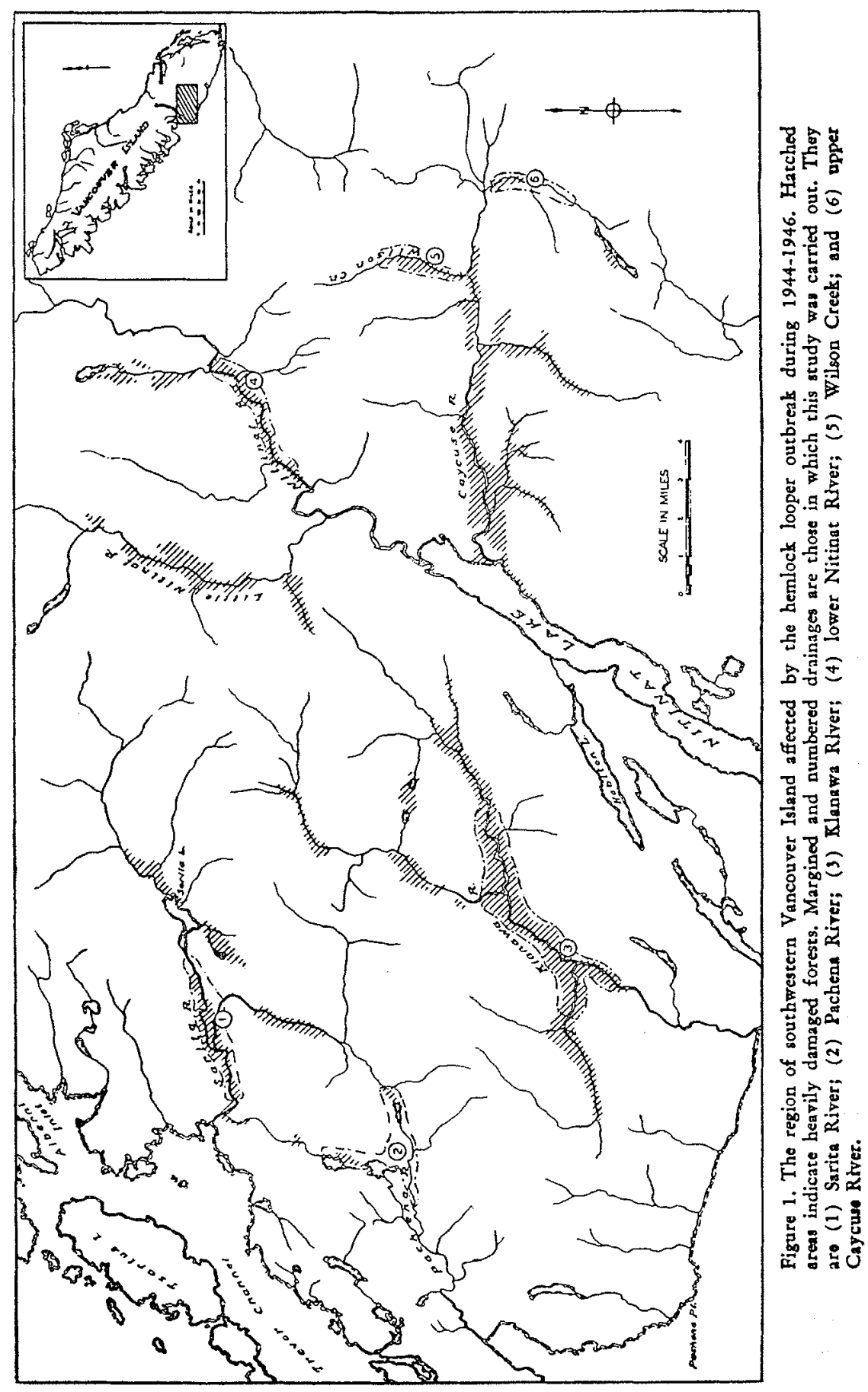




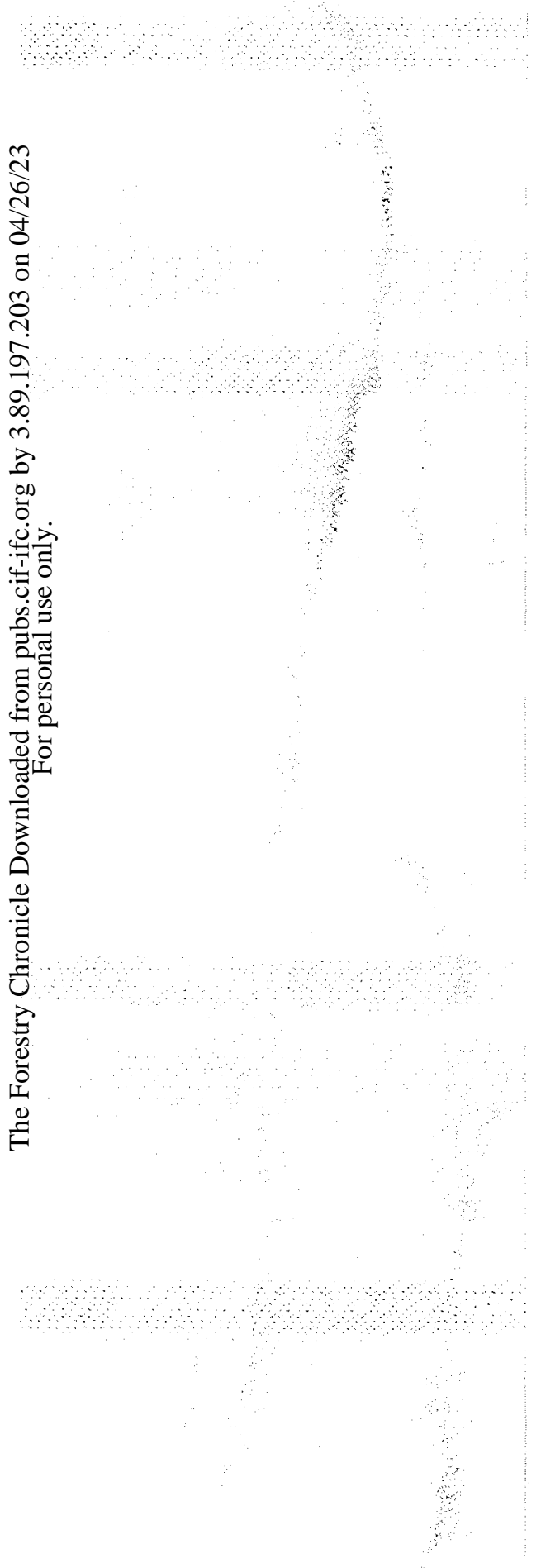

From field observations, and from examination of plot stand tables, several basic differences in forest composition and stand structure were noted. In order to lend coherence to the later analysis of mortality, these types are described as follows:

\section{Type aH.F}

This forest type is composed of all-aged hemlock and 300-year-old evenaged Douglas fir. Figure 2(a) shows the stem distribution chart upon which the distinction is made. The scattered Douglas fir overtop the hemlock so that they are relatively free of hemlock competition. This type is found in the Nitinat and Caycuse River study areas.

\section{Type eHF}

Even-aged hemlock and even-aged Douglas fir make up this forest type. The age of the hemlock varies considerably, but the stem distribution simulates the even-aged structure described by Bruce and Schumacher (2). Aside from mortality considerations, biological and management problems of this type are more closely related to even-aged than to all-aged stands.

Both species average 200 to 250 years in age. Although the number of Douglas fir per acre in this type is greater than in the Type aH.F, the average diameter, crown size, and basal area per acre are smaller. The crown canopies of both the Douglas fir and hemlock are more or less on the same plane. The stands in the Wilson Creek drainage characterize this type.

\section{Type eHA}

Within this type two stand variations occur. One consists of a mixture of even-aged hemlock and amabilis fir, while the other is composed of pure even-aged hemlock. These variations are illustrated in Figures 2(c) and (d). The even-aged designation must be qualified by the fact that a younger evenaged class of both species is commencing to replace the older stands. The average age of the mature portion of the stands of both species is about 200 years. This type is represented in the Klanawa, Pachena, and Sarita River study areas.

\section{Sample Plots}

\section{Basis Of Study}

The hemlock looper outbreak in this region developed in 1943 and 1944, and by 1945 extensive areas of forests were severely defoliated. Damage continued during 1946, but in the same season the outbreak collapsed. The rapid and thorough eradication of the population is credited chiefly to a virus disease of the insect. As a basis for this study, 40 rectangular and 31 circular onefifth acre plots were established in the six study areas during 1946 and the spring of 1947. The plot locations were selected on the basis of stand composition and degree of damage. It must be kept in mind that although western bemlock is the preferred host of this insect, Douglas fir, amabilis fir and sitka spruce are attacked with almost equal severity in localities supporting high looper populations. It was necessary, therefore, to sample all of the host species associations in the affected areas. 

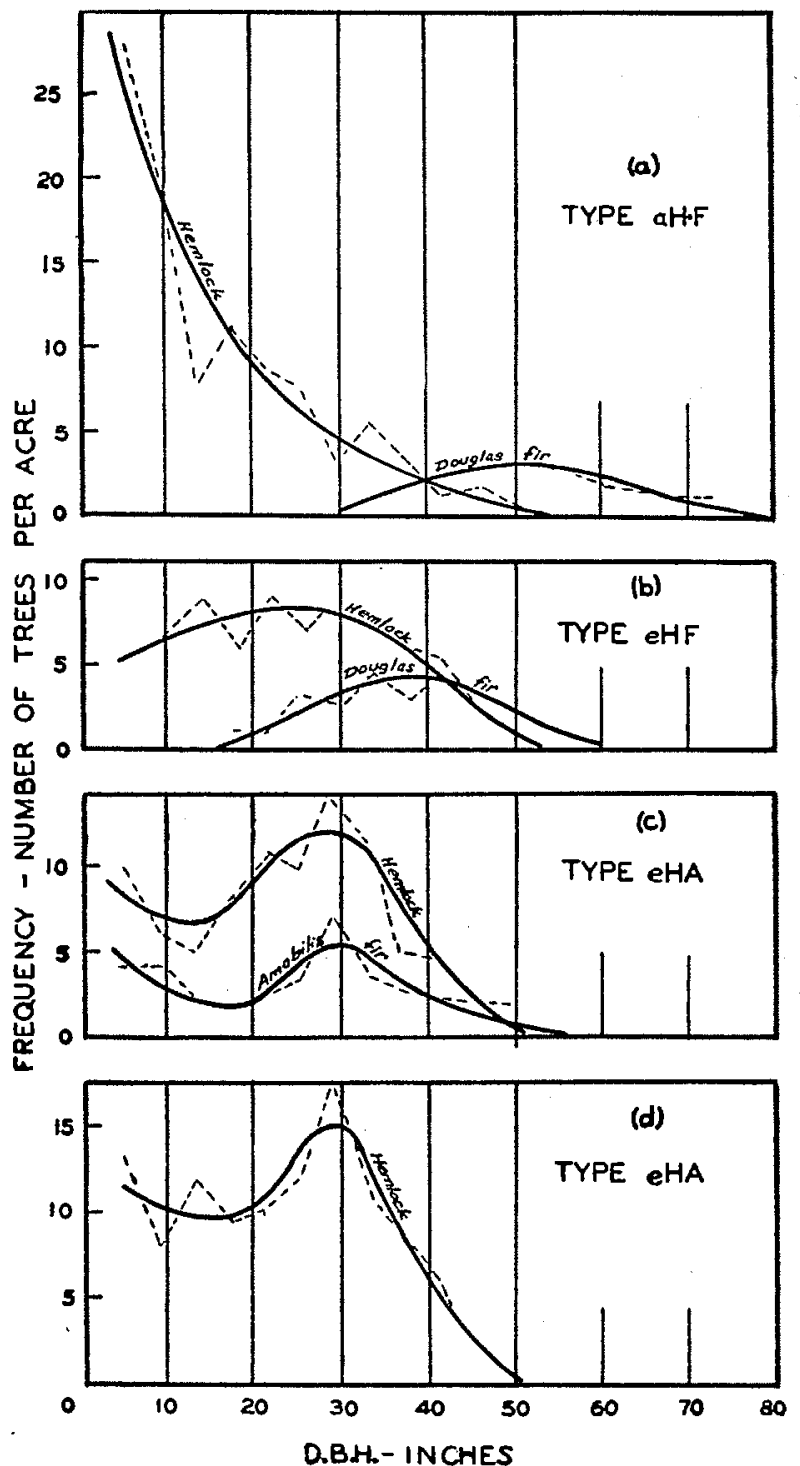

Fig. 2 Stem distribution charts of the principal forest types studied.

(a) Type aH.F: all-age hemlock and 300-year even-aged Douglas fir.

(b) Type eHF: Even-aged hemlock-Douglas fir.

(c) Type eHA: Even-aged hemlock-amabilis fir.

(d) A variation of Type eHA wherein only pure even-aged hemlock persists. 


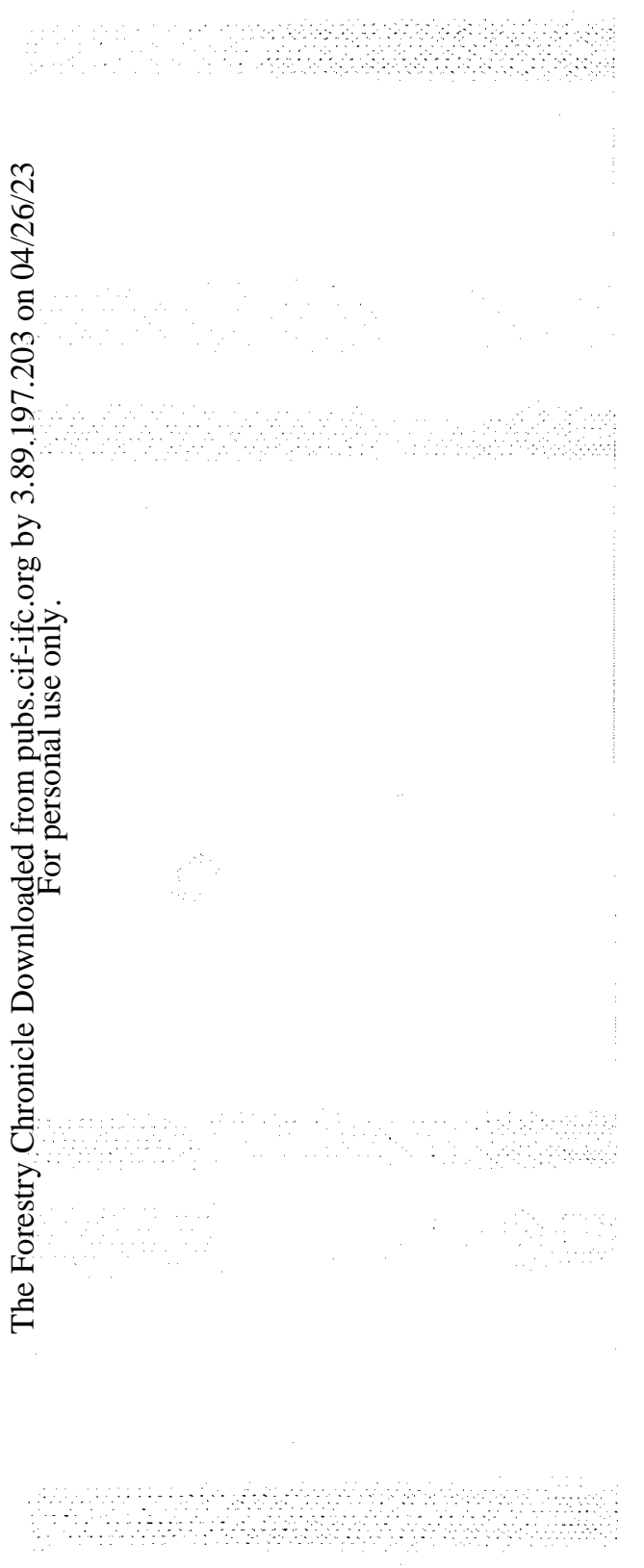

Data that were collected included plot elevation and aspect, and tree descriptions of all species over 4 inches $d$. $b$. $h$. These tree data were measures of d. b. h. and total height, and estimates of percentage defoliation, crown class, crown shade, and crown size.

\section{Yearly Change}

The plots were examined each summer up to, and including 1950, in order to follow the trend of mortality and to attempt to predict the eventual fate of partially defoliated trees. The yearly distribution of mortality is illustrated in Figure 3. Death of a tree was established only by visual symptoms. Complete lack of foliaga or foliage color changes that were associated with butt cambial discoloration were the criteria used.

Very few trees had died by the end of 1946 . Those trees that died between 1946 and 1947 had been very heavily defoliated. Many of those that succumbed in the ensuing three years put out some new foliage after defoliation but prior to death. Also, large populations of secondary bark mining insects were found in those trees that died in the later years. The principal secondaries attacking each species were: Tetropium velutinum Lec. in hemlock; Dendroctonus pseudotsugae Hopk. in Douglas fir; Pseudohylesinus spp. in amabilis fir, and Dendroctonus obesus (Mann.) in Sitka spruce.

Attempts to predict subsequent mortality each year by grouping the trees into condition classes were fruitless. Although the wealth of new foliage in 1947 prompted optimism, many trees classified as "recovery apparent", succumbed in later years. The best estimates of eventual mortality were actually made during 1946 and the spring of 1947 before adventitious growth masked the intensity of defoliation.

Plot examinations were terminated in 1950 because over one-third of the plots had been cut in salvage logging and most of the surviving trees appeared to have regained full vigor. The value of later records of tree death would be problematical since one would have difficulty in attributing cause of death to looper damage rather than to "normal" mortality that may be expected in an overmature forest.

\section{Forest Succession}

In areas of heavy kill, the dead trees opened the stands and thus exposed the surviving trees to greater wind damage. Many of these survivors were windthrown and others were injured by falling debris from the dead trees. In Types eHF and eHA, where advanced growth and regeneration were light, the addition of windthrow and injury has tended to desolate the areas. On the other hand, Type aH.F not only suffered less mortality (see later analysis) but also retained a relatively large number of thrifty young trees per acre. In another decade these stands will probably show few signs of looper damage.

In all areas of heavy kill, ground cover plants have quickly taken over the sites. Although the succulent elderberry, Sambucus glauca Nutt., responded most quickly to release, the more persistent salmonberry, Rubus spectabilis Pursh., presents a greater problem to regeneration. Even the tolerant hemlock has little success in competing with the dense canopy of this plant. It is unlikely that conifers will become established for many decades unless the salmonberry is eradicated. 


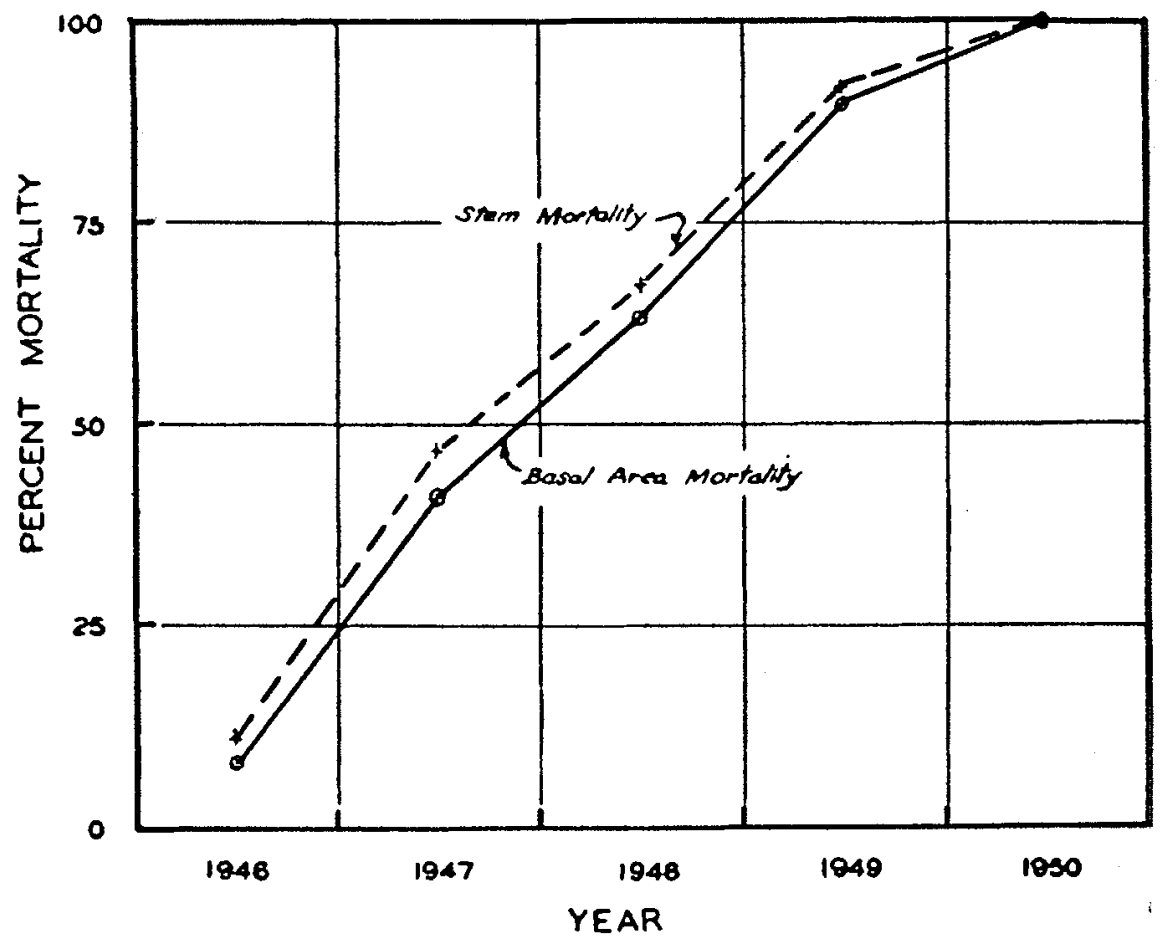

Figure 3. The yearly distribution of mortality for all species subsequent to the cessation of damage. The 1950 mortality was taken as the total attributable to the hemlock looper outbreak, and the yearly mortality has been expressed as a percentage thereof.

\section{Tabular Investigation Of Plot Data}

From the basic data at hand, it appears desirable to investigate the relationship of the variables measured or estimated on the plots to the mortality of individual trees. Since most of these data involve many variables and because descriptive estimates were used, statistical treatment is not practical. Tabular analyses do, however, indicate the variables most clearly associated with tree death.

\section{Defoliation}

Estimates of percentage defoliation were used for assessing the damage on each tree. Hemlock looper larvae feed on both old and current foliage, and on all parts of the tree's crown, although defoliation is usually heavier on the top and on exposed sides. It was necessary, therefore, to view each tree from two or three sides to obtain an average estimate for the whole crown. The task of checking these estimates against leaf counts of both undamaged and partially defoliated trees appeared to be so overwhelming that it was not 
attempted. Herein lies the basic weakness of the damage appraisal which, unfortunately, cannot be overcome.

Since heavy hemlock looper populations rarely persist more than three years, the period of severe damage is relatively brief. Hence only the cumulative defoliation suffered at the termination of the outbreak was used as the damage index. Maximum defoliation was always used to determine this index. In most of the plots maximum defoliation was best determined during the autumn of 1946. However, in a few plots, 1946 feeding was so light that the spring defoliation estimates were higher. Hereafter maximum defoliation is referred to simply as the percentage defoliation.

The results of the tabular defoliation-mortality analysis are presented in Figure 4. Owing to the few Douglas fir, amabilis fir and Sitka spruce in each tive per cent defoliation class, these species data have been grouped into the three broad classes shown in the graphs. The number of hemlock is sufficient, however, to show the relationship in five per cent classes. The interesting features of this analysis are: (a) survival of many trees of all species that were defoliated over 80 per cent; (b) relatively high mortality of Douglas fir and amabilis fir in the 50 to 70 per cent class in comparison to hemlock mortality; and (c) the nil-mortality of amabilis fir and spruce that were defoliated less than 50 per cent.

\section{Diameter}

The following table shows that for all species except Douglas fir, the average diameter of dead trees was greater than that of surviving trees.

TABLE I

Comparison of the Average Diameter of Dead and SurViving Trees by Species

\begin{tabular}{lcc}
\hline Species & \multicolumn{2}{c}{ Average D.B.H. (inches) } \\
Dead Trees \\
\hline Hemlock & $20(589) *$ & $27(480)$ \\
Douglas fir & $51(64)$ & $38(36)$ \\
Amabilis fir & $21(132)$ & $29(47)$ \\
Sitka spruce & $38(36)$ & $44(54)$ \\
\hline
\end{tabular}

"Basis-Number of Trees

The graphs of basal area mortality presented in the preceding section support this evidence, and in addition, they show that the mortality of larger trees (again excepting Douglas fir) was higher in all defoliation classes. The survival of the large Type aH.F Douglas fir accounts for the trend difference of this species.

\section{Aspect and Elevation}

Only the hemlock data were sufficient for investigation of all the classes of these variables. A polygonal representation of aspect and mortality indicates 

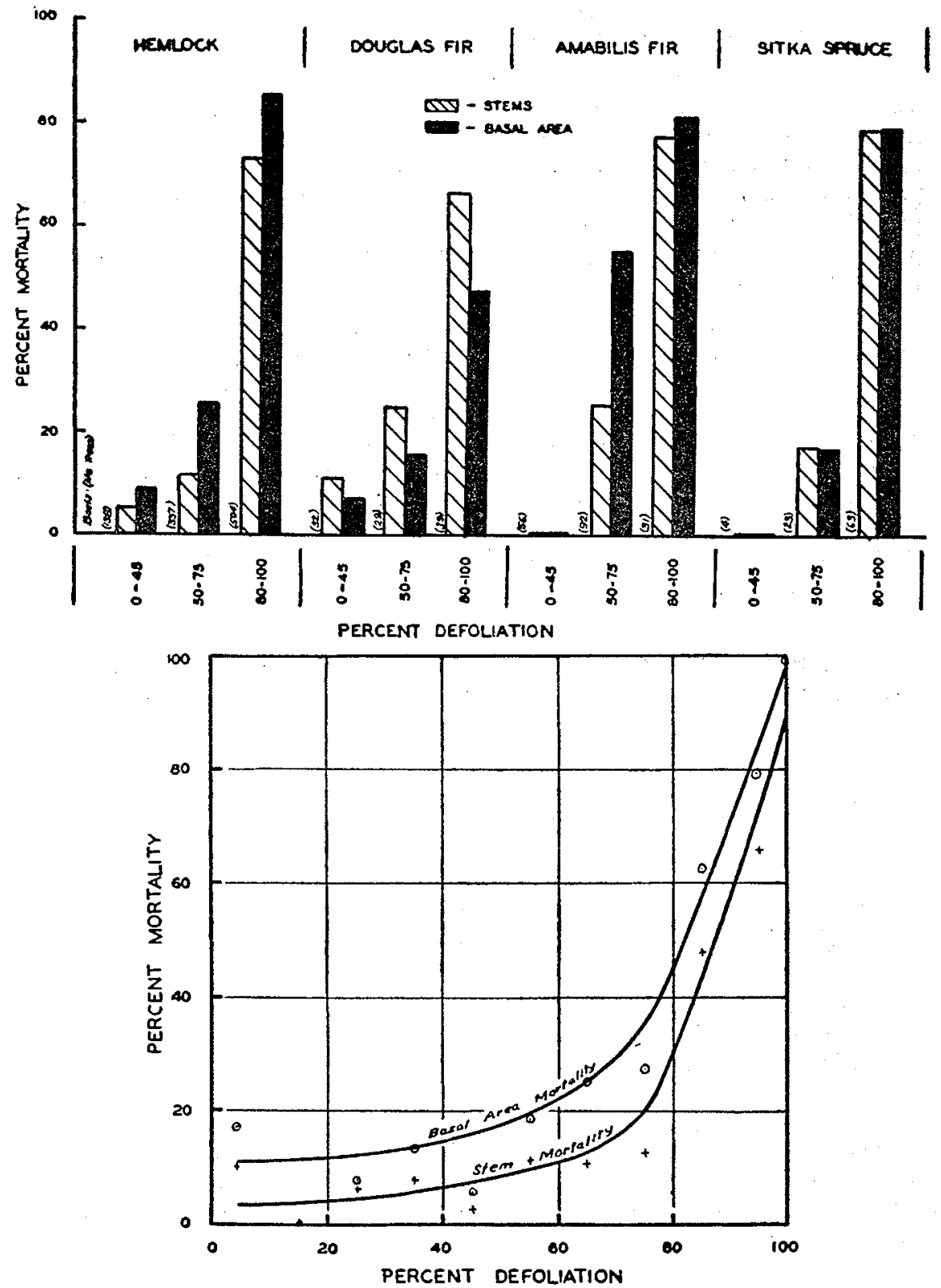

Figure 4. The relationship of basal area and stem mortality to percentage defoliation. (a) Bar graph showing the mortality relationship of each species to broad defoliation classes. (b) Proohand curves fitted to the hemlock data to indicate the relationship of mortality to fire per cont damage classes. 

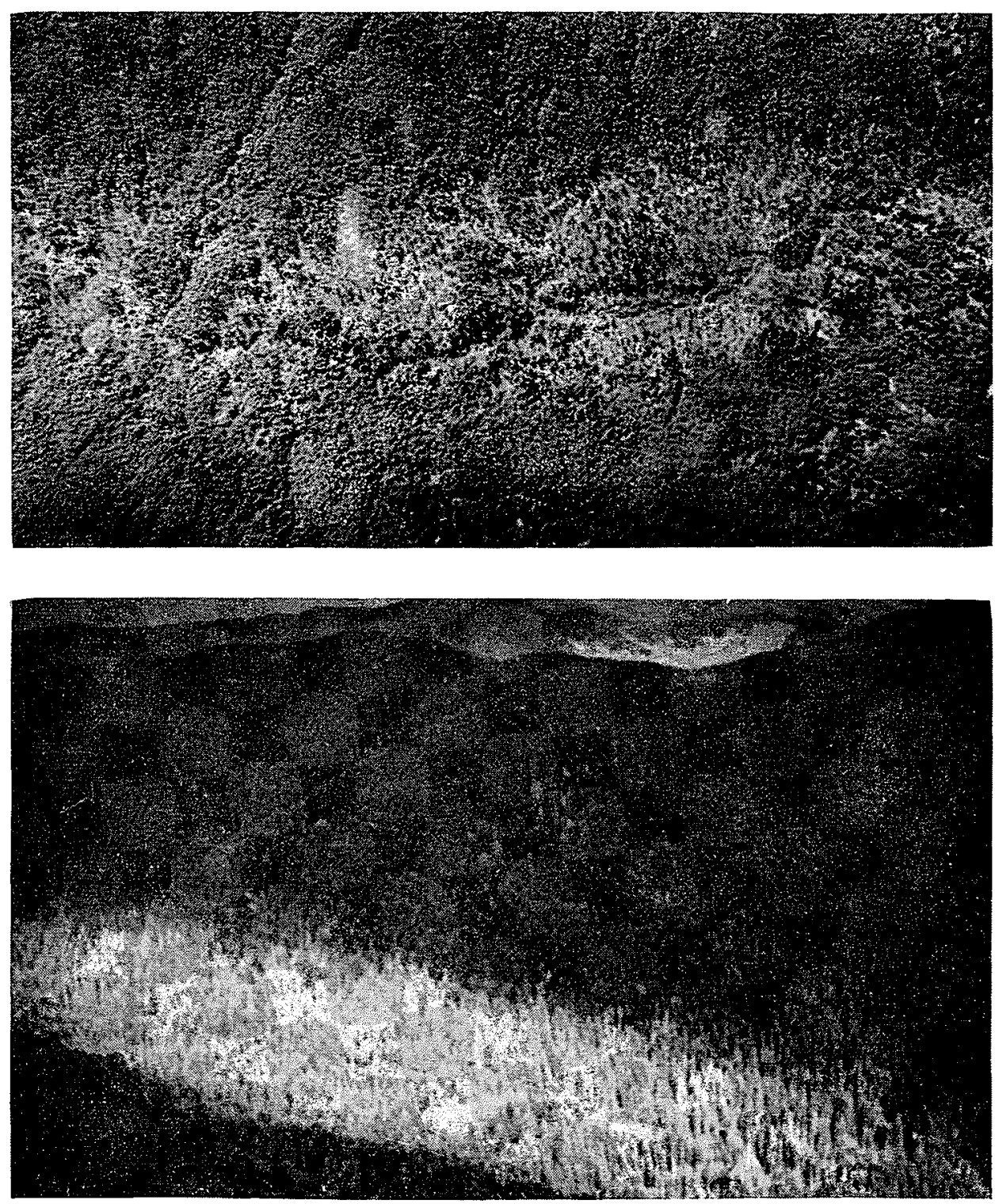

Figure 5. Oblique and vertical acrial photographs of hemlock looper damage in Wilson Creek (sec study area (5) in figure 1). The oblique view was photographed during 1947 while the crowns were still intact, whereas the vertical view was taken during 1951 when only the dead boles remained. These photographs are reproduced with the permission of British Columbia Forest Products Co. Ltd., and the British Columbia Government Air Photograph Service respecrively. (The vertical view is part of photograph B.C. 1238: 15.) 
TABLE II

The Relationship of Crown Class, Shade and Size to Percentage Stem Mortality of Western Hemlock, Douglas Fir, Amabilis Fir and SitKa SPRUCE

\begin{tabular}{|c|c|c|c|c|c|}
\hline $\begin{array}{l}\text { Crown } \\
\text { Character- } \\
\text { istic }\end{array}$ & $\begin{array}{l}\text { Intermediate } \\
\text { Classifi- } \\
\text { cations }\end{array}$ & $\begin{array}{c}\text { Basis } \\
\text { (No. Trees) }\end{array}$ & $\begin{array}{l}\text { Average } \\
\text { D.B.H. } \\
\text { (inches) }\end{array}$ & $\begin{array}{c}\text { Average } \\
\text { Defoliation } \\
(\%)\end{array}$ & $\begin{array}{c}\text { Stem } \\
\text { Mortality } \\
(\%)\end{array}$ \\
\hline \multirow{5}{*}{$\begin{array}{l}\text { (a) Hemlock } \\
\text { Crown Class }\end{array}$} & & & & & \\
\hline & Dominant & 368 & 33 & 73 & 58 \\
\hline & Co-dominant & 234 & 16 & 72 & 36 \\
\hline & Intermediate & 244 & 24 & 73 & 50 \\
\hline & Suppressed & 274 & 9 & 71 & 23 \\
\hline \multirow[t]{3}{*}{ Crown Shade } & Exposed & 354 & 32 & 77 & 63 \\
\hline & Partly Shaded & 465 & 28 & 70 & 52 \\
\hline & Fully Shaded & 190 & 11 & 69 & 33 \\
\hline \multirow[t]{3}{*}{ Crown Size } & Large & 300 & 29 & 63 & 43 \\
\hline & Medium & 489 & 29 & 72 & 37 \\
\hline & Small & 209 & 15 & 72 & 43 \\
\hline \multicolumn{6}{|c|}{ (b) Douglas fir } \\
\hline \multirow[t]{4}{*}{ Crown Class } & Dominant & 77 & 51 & 59 & 27 \\
\hline & Co-dominant & 15 & 33 & 70 & 67 \\
\hline & Intermediate & 7 & 26 & 88 & 86 \\
\hline & Suppressed & 1 & 31 & 10 & 0 \\
\hline \multirow[t]{3}{*}{ Crown Shade } & Exposed & 60 & 53 & 59 & 27 \\
\hline & Partly Shaded & 23 & 37 & 64 & 48 \\
\hline & Fully Shaded & 5 & 30 & 82 & 80 \\
\hline \multirow[t]{3}{*}{ Crown Size } & Large & 35 & 58 & 64 & 23 \\
\hline & Medium & 34 & 42 & 56 & 44 \\
\hline & Small & 31 & 36 & 66 & 45 \\
\hline \multicolumn{6}{|c|}{ (c) Amabilis fir } \\
\hline \multirow[t]{4}{*}{ Crown Class } & Dominant & 62 & 36 & 47 & 34 \\
\hline & Co-dominant & 36 & 25 & 51 & 33 \\
\hline & Intermediate & 26 & 12 & 54 & 23 \\
\hline & Suppressed & 80 & 7 & 48 & 12 \\
\hline \multirow[t]{3}{*}{ Crown Shade } & Exposed & 70 & 35 & 52 & 39 \\
\hline & Partly Shaded & 81 & 17 & 45 & 14 \\
\hline & Fully Shaded & 53 & 8 & 52 & 21 \\
\hline \multirow[t]{3}{*}{ Crown Size } & Large & 47 & 32 & 45 & 13 \\
\hline & Medium & 94 & 21 & 43 & 16 \\
\hline & Small & 39 & 19 & 51 & 28 \\
\hline \multicolumn{6}{|l|}{ (d) Sitka spruce } \\
\hline \multirow[t]{4}{*}{ Crown Class } & Dominant & 57 & 47 & 81 & 51 \\
\hline & Co-dominant & 17 & 37 & 86 & 65 \\
\hline & Intermediate & 13 & 24 & 90 & 92 \\
\hline & Suppressed & 2 & 13 & 80 & 50 \\
\hline \multirow[t]{3}{*}{ Crown Shade } & Exposed & 43 & 50 & 85 & 58 \\
\hline & Partly Shaded & 23 & 36 & 92 & 70 \\
\hline & Fully Shaded & 6 & 18 & 90 & 83 \\
\hline \multirow{3}{*}{ Crown Size } & Large & 20 & 50 & 82 & 70 \\
\hline & Medium & 23 & 41 & 83 & 48 \\
\hline & Small & 12 & 34 & 88 & 58 \\
\hline
\end{tabular}


that mortality was higher on the northern and eastern aspects than on the southern and western aspects. However, the average mortality on each aspect can be explained by either average defoliation or average diameter.

No relationship can be found between absolute elevation and mortality, but an indication of less mortality with increase in altitude above the valley floor can be demonstrated. Again, however, this difference appears to be more closely associated with tree size and degree of damage. The effect of this combination of higher defoliation and higher mortality on valley bottom stands is vividly illustrated in Figure 5.

\section{Crown Characteristics}

Qualitative estimates of crown class, shade and size were taken for most trees, but their value is strongly limited by the lack of quantitative measures. Table II shows the percentage stem mortality for each classification of each species. In most cases, discernible mortality trends are the same as, or are the inverse of defoliation or diameter trends. A break in the trend of one of these variables is always associated with a break in trend of at least one of the other two (Table II).

An examination of the tables reveals the following broad results (a) Crown Class-hemlock and amabilis fir mortality was heavier with increasing dominance. Douglas fir and spruce mortality trends were the reverse; (b) Crown Shade-hemlock and amabilis fir mortality was heavier with greater exposure, while Douglas fir and spruce death rates decreased with greater crown exposure; (c) Crown Size-no trend is apparent for hemlock and spruce, but smaller crown Douglas fir and amabilis fir suffered higher mortality than those trees with large crowns.

\section{Statistical Treatment of Plot Data}

\section{Method}

The objective is to relate stand mortality to forest composition and to hemlock looper defoliation by the use of multiple regression. Schumacher and Chapman (9) have demonstrated the theoretical background of the use of regression in double sampling forestry problems. Double sampling refers to the method whereby a difficult and costly dependent variable $(y)$ is related to one or more easily measured independent variables $\left(X_{1}, X_{2} \ldots \ldots X_{n}\right)$ by regression analysis of a small sample. An estimate of the total value (Y) of the population universe can then be drawn from a large sample of independent variables that are modified by the parameters established by the small sample regression. In order to meet the theoretical requirements, the large sample of the independent variables must be taken at random. On the other hand, it is unnecessary to randomize the small sample of the independent variables provided that the dependent variable is taken at random.

In this particular problem, forest composition and defoliation were selected as the independent variables, and mortality was classed as a dependent variable. Since the mortality was an unknown at the time the plots were established, 
one may safely consider that this dependent variable was randomly measured. An estimate of the total mortality in another outbreak area may be obtained by modifying large sample measures of composition and damage by the relationships established herein.

\section{Choice of Variables}

Economically and biologically a large tree represents a greater proportion of a forest than a small tree. Therefore, in expressing forest composition it is only logical to give greater weight to the larger trees. This was accomplished with facility by summing the total breast height basal area of each species on a sample plot. Similarly, the mortality was expressed by the sum of the basal area of dead trees by species in each plot. Basal area also has the advantage of being proportional to tree volume, so that the results can readily be converted to economic values.

The damage variables were expressed as the plot sums of the proportions of defoliation. Proportions were used in place of percentages in order to reduce the sums to about the same magnitude as the basal area summations.

One other variable which was added to the expression is the plot sum of the cross products of proportional defoliation and basal area. This consolidation was particularly valuable in that it converted the measure of damage to a variable that retained the weight given to larger trees by basal area.

With these expressions of mortality, forest composition and damage, the basic regression equation was set up as follows:

$$
\begin{aligned}
M_{H}+M_{F}+M_{B}+M_{S}= & a_{1}\left(B_{H}\right)+a_{2}\left(B_{F}\right)+a_{3}\left(B_{B}\right)+a_{4}\left(B_{8}\right)+a_{5}\left(P_{H}\right) \\
& +a_{6}\left(P_{F}\right)+a_{7}\left(P_{B}\right)+a_{8}\left(P_{S}\right)+a_{9}\left(B_{H} P_{H}\right) \\
& +a_{10}\left(B_{Y} P_{F}\right)+a_{11}\left(B_{B} P_{B}\right)+a_{12}\left(B_{S} P_{S}\right) \\
\text { Where } &
\end{aligned}
$$

$\mathbf{M}=$ Plot sum of the basal area of dead trees in square feet

$\mathrm{B}=$ Plot sum of the basal area of both living and dead trees

$\mathrm{P}=$ Plot sum of the proportions of defoliation

$\mathrm{BP}=$ Plot sum of the basal area times proportion defoliation of each tree.

$a_{1} \cdot . \quad \cdot a_{12}=$ Regression coefficients.

and where the subscripts H, F, B, and S refer to western hemlock, Douglas

fir, amabilis fir, and sitka spruce respectively.

Briefly, the general procedure in the analysis is the calculation of the normal equations; the solution of these equations by the method of least squares; and the analysis of variance in which the validity of the regression coefficients is tested against the statistic " $F$ ".

Analysis

These data were first analysed on this basis in the author's thesis (6) following the 1949 annual plot examination. At the time it was necessary to estimate the amount of mortality that would occur after 1949. These estimates proved to be reasonably accurate, but it was deemed necessary to re-analyse on the basis of the 1950 data and to carry the investigation further in some respects.

The earlier analysis produced several relationships which are now summarized in order to clarify the final analysis:

$\mathrm{M}_{\mathrm{H}}=-0.044\left(\mathrm{~B}_{\mathrm{H}}\right)+0.889\left(\mathrm{~B}_{\mathrm{H}} \mathrm{P}_{\mathrm{H}}\right)-0.233\left(\mathrm{~B}_{\mathrm{F}}\right)+2.577\left(\mathrm{P}_{\mathrm{F}}\right)$

$\mathbf{M}_{\mathbf{F}}=-0.272\left(\mathrm{~B}_{\mathrm{F}}\right)+9.494\left(\mathrm{P}_{\mathrm{E}}\right)$ 


$$
\begin{aligned}
& M_{B}=-0.676\left(B_{B}\right)+2.159\left(B_{B} P_{B}\right) \\
& M_{8}=1.058\left(B_{\mathrm{B}}\right)-4.373\left(P_{8}\right)
\end{aligned}
$$

The influence of Douglas fir on bemlock attributed to the fact that Type aH.F hemlock suffered less mortality than hemlock in the other types. The obvious error of the negative value of the $\mathbf{P}_{\mathbf{B}}$ coefficient in equation [5] was attributed to the small sample, the narrow range of defoliation in the sample, and to a possible error in the method of estimating damage. It was demonstrated that heavy top defoliation increased the chance of spruce death after 1947 more than the estimate of average defoliation over the whole crown.

When the final analysis was first started, the plots were split into groups representing each of five forest types. Unfortunately, there were so few plots in each group that validity tests were seriously limited by the lack of error degrees of freedom. Two broad groupings have proven valuable in elucidating the variances of hemlock and Douglas fir mortality between stand Types eHF and eHA. Therefore, all of the Type aH.F plots have been analysed separately from the remainder of the data.

Since the Sitka spruce plots proved valueless in the thesis analysis and in a separate spruce type test, they were deleted from the final investigation.

Another refinement of the final analysis that must be mentoned is the exclusion of all unmerchantable trees (i.e. trees less than 12 inches d.b.h.) from the plot data. This rejection was advisable for two reasons. First, the expressions are intended for use on a merchantable basis. Secondly, in stands having a large number of heavily defoliated small trees, the "P" values would be unduly high in relation to the basal area affected.

As in the initial analysis, it has been necessary to delete the few cedar, white pine and windthrown trees from the data. The effect of these minor rejections on the plot sums is negligible.

\section{Forest Type aH.F Analysis}

The basic data for this regression were drawn from 14 plots in the Nitinat and Caycuse River study areas ${ }^{3}$. With only hemlock and Douglas fir in this type, the regression equation is simply:

$$
\begin{aligned}
\mathbf{M}_{\mathrm{H}}= & \mathrm{a}_{1}\left(\mathrm{~B}_{\mathrm{H}} \mathbf{P}_{\mathrm{H}}\right)+\mathrm{a}_{2}\left(\mathbf{B}_{\mathrm{F}} \mathbf{P}_{\mathrm{F}}\right)+\mathrm{a}_{3}\left(\mathrm{~B}_{\mathrm{H}}\right)+\mathrm{a}_{4}\left(\mathbf{B}_{\mathrm{F}}\right)+\mathrm{a}_{5}\left(\mathbf{P}_{\mathrm{H}}\right) \\
& +\mathrm{a}_{\mathbf{0}}\left(\mathbf{P}_{\mathrm{F}}\right)
\end{aligned}
$$

Since there was no fir mortality in this type it has not been necessary to include $\left(M_{F}\right)$ in the expression. Following the forward solution of the normal equations, the analysis of variance (Table III) revealed only $\left(B_{\mathrm{H}} \mathrm{P}_{\mathrm{H}}\right)$ as a significant variable. The calculation of $a_{1}$ gave the equation:

$$
\mathbf{M}_{\mathbf{B}}=0.473\left(B_{\mathrm{B}} \mathbf{P}_{\mathbf{B}}\right)
$$

Forest Types $e H F$ and $e H A$ Analysis

The addition of hemlock-amabilis fir plots from Type eHA required the addition of the four amabilis fir variables to equation [6]. Thirty-seven plots

\footnotetext{
3 The basic data and the normal equations for these regression analyses are on file at the Victoria Laboratory and are available upon request.
} 
TABLE III

Analysis of Variance of Basal Area Mortality of Hemlock $\left(M_{H}\right)$ in TYPE aH.F STANDS

\begin{tabular}{|c|c|c|c|}
\hline \multicolumn{2}{|c|}{ Source } & \multirow{2}{*}{$\begin{array}{c}\text { Degrees of } \text { Freedom } \\
1\end{array}$} & \multirow{2}{*}{$\frac{\text { Sums of Squares }}{5,209.39 * *}$} \\
\hline$\overline{\text { Regression } 0}$ & on $B_{H} P_{H}$ & & \\
\hline$"$ & $": \mathbf{B}_{\mathbf{F}} \mathbf{P}_{\mathbf{E}}$ & 1 & 213.67 \\
\hline " & $" \mathbf{B}_{\mathrm{H}}$ & 1 & 292.76 \\
\hline$"$ & $" \mathrm{~B}_{\mathrm{F}}$ & 1 & 3.21 \\
\hline$"$ & $" P_{H}$ & 1 & 47.24 \\
\hline$"$ & $" P_{F}$ & 1 & 12.07 \\
\hline \multicolumn{2}{|c|}{ Due to Regression } & 6 & $5,778.34$ \\
\hline \multicolumn{2}{|c|}{ Independent of Reg. } & 8 & 606.89 \\
\hline \multicolumn{2}{|l|}{ Total } & 14 & $6,385.23$ \\
\hline
\end{tabular}

Mean Square of $\mathrm{M}_{\mathrm{H}}=75.8$

* Mean Square Significant at $1 \%$ level

were available for this regression. The reduction of the normal equations and subsequent analysis of variance (Table IV (a) ) shows the significant variables involved. Since $\left(B_{H}\right),\left(B_{F}\right),\left(P_{H}\right)$ and $\left(P_{F}\right)$ were not significant with any of the three dependent variables, they were deleted; the matrix was again solved to give the modified analysis of variance shown in Table IV (b).

A peculiarity of multiple regression analysis should be brought to the reader's attention at this point. When it is necessary to handle several independent variables, the order in which they are arranged in the normal equations is important. The variables first removed from the matrix tend to use up a large portion of the sums of squares that are available for testing variables placed in the latter positions of the sequence. Frequently anomalies arise from this effect that can be revealed by rearrangement of the sequence of the variables. One example is displayed in Table IV where $\left(B_{F} P_{F}\right)$ apparently affects the mortality of amabilis fir. This is an obvious chance effect because Douglas fir and amabilis fir are not coincident on any of the plots. For this reason, and to reduce the number of significant variables to a minimum, it has been necessary to rearrange the independent variables with each dependent variable separately.

Hemlock mortality was adequately expressed by $\left(\mathrm{B}_{\mathrm{H}} \mathrm{P}_{\mathrm{H}}\right)$ without further re-arrangement. The solved coefficient gave:

$\mathrm{M}_{\mathrm{H}}=0.934\left(\mathrm{~B}_{\mathrm{H}} \mathrm{P}_{\mathrm{H}}\right)$

In comparison to equation [7], this $a_{1}$ value is relatively high. The simplification and causal clarification of hemlock mortality compared to equation [2] justifies the segregation of the all-age forest type.

The rearrangement of variables affecting Douglas fir mortality revealed $\left(B_{F}\right.$ $\mathbf{P}_{\mathrm{F}}$ ) as the principal causal factor. This arrangement and its validity test is shown in Table $V$. The solution of $a_{2}$ gave:

$\mathrm{M}_{\mathrm{F}}=1.039\left(\mathrm{~B}_{\mathrm{F}} \mathrm{P}_{\mathrm{F}}\right)$

Again the deletion of the nil-mortality Type aH.F fir yielded a simplification. While stem frequency is greater in Type eHF than in Type aH.F, the 
basal area per acre of the fir in the latter is higher than that of the former. Hence, this accounts for the negative value that was obtained for the coefficient of $\left(B_{F}\right)$ in equation [3]. The relative values of the last three equations are illustrated in Figure 6.

By arranging the amabilis fir variables so that they were first in order of reduction, the $\left(\mathrm{B}_{\mathrm{H}} \mathrm{P}_{\mathrm{H}}\right)$ and $\left(\mathrm{B}_{\mathrm{F}} \mathrm{P}_{\mathrm{F}}\right)$ dropped out of significance. Regardless of all arrangements of these three amabilis fir variables, all were significant (Table VI) so that they had to be retained. Solution of the regression coefficients showed that:

$$
\mathrm{M}_{\mathrm{B}}=2.380\left(\mathrm{~B}_{\mathrm{B}} \mathrm{P}_{\mathrm{B}}\right)-0.749\left(\mathrm{~B}_{\mathrm{B}}\right)-1.547\left(\mathrm{P}_{\mathrm{B}}\right)
$$

\section{TABLE IV}

Analysis of Variance of Basal Area Mortality of Hemlock, Douglas Fir and Amabilis Fir in Types eHF and eHA Stands

(a) All variables

\begin{tabular}{|c|c|c|c|c|c|}
\hline \multirow[t]{2}{*}{ Sourc } & & \multirow{2}{*}{$\begin{array}{c}\text { Degrees } \\
\text { of Freedom }\end{array}$} & \multicolumn{3}{|c|}{ Sums of Squares } \\
\hline & & & $\mathbf{M}_{\mathbf{H}}$ & $\mathbf{M}_{F}$ & $\mathbf{M}_{\mathrm{B}}$ \\
\hline$\overline{\text { Regression }}$ & on $B_{H} P_{H}$ & 1 & $82,064.91 *$ & $1,926.90^{*}$ & $1,010.99^{* *}$ \\
\hline 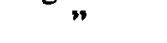 & $" \mathrm{~B}_{\mathrm{F}} \mathrm{P}_{\mathrm{F}}$ & 1 & 9.40 & $11,816.00^{*}$ & $164.08 * *$ \\
\hline " & $" \mathrm{~B}_{\mathrm{B}} \mathrm{P}_{\mathrm{B}}$ & 1 & 66.28 & 0.00 & $4,118.49 * *$ \\
\hline " & $" \mathbf{B}_{\mathbf{B}}$ & 1 & 202.79 & 4.20 & 31.07 \\
\hline$"$ & $" B_{F}$ & 1 & 62.36 & 65.80 & 9.05 \\
\hline " & $" \mathrm{~B}_{\mathrm{B}}$ & 1 & 6.89 & 0.46 & $422.24 * *$ \\
\hline " & $" \quad P_{E}$ & 1 & 4.52 & 12.07 & 1.09 \\
\hline$"$ & $" \mathbf{P}_{F}$ & 1 & 49.40 & 3.16 & 0.26 \\
\hline$"$ & $" \quad \mathbf{P}_{\mathbf{B}}$ & 1 & 2.80 & 0.06 & $115.63 *$ \\
\hline \multirow{2}{*}{\multicolumn{2}{|c|}{$\begin{array}{l}\text { Due to Regression } \\
\text { Independent of Reg. }\end{array}$}} & 9 & $82,469.35$ & $13,828.65$ & $5,872.90$ \\
\hline & & 28 & $4,078.91$ & $1,026.27$ & 525.13 \\
\hline \multicolumn{2}{|l|}{ Total } & 37 & $86,548.26$ & $14,854.92$ & $6,398.03$ \\
\hline
\end{tabular}

(b) $\left(\mathrm{B}_{\mathrm{H}}\right),\left(\mathrm{B}_{\mathrm{F}}\right),\left(\mathrm{P}_{\mathrm{H}}\right)$ and $\left(\mathrm{P}_{\mathrm{F}}\right)$ Removed

\begin{tabular}{|c|c|c|c|c|c|}
\hline Regression & on $B_{H} P_{H}$ & 1 & $82,064.91^{* *}$ & $1,926.90^{* *}$ & $1,010.99^{* *}$ \\
\hline " & $" \quad \mathbf{B}_{F} P_{F}$ & 1 & 9.40 & $11,816.00 * *$ & $164.08 * *$ \\
\hline " & $\mathbf{B}_{B} P_{B}^{-}$ & 1 & 66.28 & 0.00 & $4,118.49 * *$ \\
\hline$"$ & $B_{B}$ & 1 & 24.24 & 0.00 & $462.29 * *$ \\
\hline$"$ & $" \quad \mathbf{P}_{\mathbf{B}}$ & 1 & 1.39 & 0.00 & $114.93^{*}$ \\
\hline \multirow{2}{*}{\multicolumn{2}{|c|}{$\begin{array}{l}\text { Due to Regression } \\
\text { Independent of Reg. }\end{array}$}} & 5 & $82,166.22$ & $13,742.90$ & $5,870.78$ \\
\hline & & 32 & $4,382.04$ & $1,112.02$ & 527.25 \\
\hline \multicolumn{2}{|l|}{ Total } & 37 & $86,548.26$ & $14,854.92$ & $6,398.03$ \\
\hline
\end{tabular}

Mean Squares: $\mathrm{M}_{\mathrm{H}}=136.9 ; \mathrm{M}_{\mathrm{F}}=34.8 ; \mathrm{M}_{\mathrm{B}}=16.5$.

* Mean Square significant at $1 \%$ level.

- Mean Square significant at 5\% level. 
TABLE V

Analysis of Variance of Basal Area Mortaltty of Douglas fir $\left(M_{F}\right)$ IN TYPE eHF Stands

\begin{tabular}{lccc}
\hline \multicolumn{1}{c}{ Source } & Degrees of & Freedom & Sums of Squares \\
\hline Regression on $\mathrm{B}_{F} \mathrm{P}_{\mathrm{F}}$ & 1 & $13,742.89^{* *}$ \\
Added effect of & & \\
non-sig. variables & 4 & 0.00 \\
\hline Due to Regression & 5 & $13,742.89$ \\
Independent of Reg. & 32 & $1,112.03$ \\
\hline Total & 37 & $14,854.92$ \\
\hline ** Mean Square significant at 1\% level. &
\end{tabular}

TABLE VI

analysis of Variance of Basal Area Mortality of Amabilis Fir $\left(\mathrm{M}_{\mathrm{B}}\right)$ IN TYPE eHA STANDS

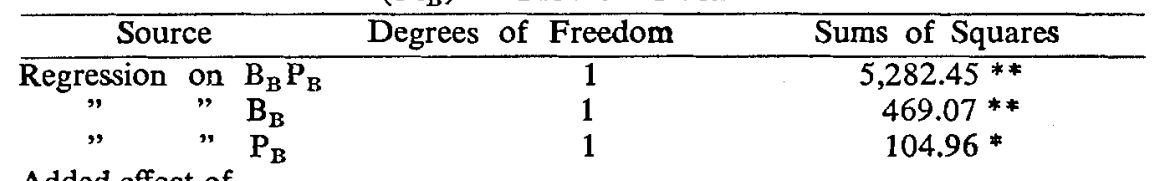

Added effect of non-sig. variables

Due to Regression

Independent of Reg.

Total

** Mean Square significant at $1 \%$ level.

* Mean Square significant at $5 \%$ level.

\section{Discussion}

The results of all of these relationships can be adapted to future damage surveys by simply modifying standard timber cruising techniques. In order to obtain estimates of maximum defoliation, the surveys will have to be carried out during the autumn, winter, and spring following the collapse of a hemlock looper outbreak. It will be necessary to type the stands according to species composition and age structure. In addition to the usual volume tallies, the proportion of foliage lost by each tree should be recorded. An estimate of the expected mortality can be calculated by multiplying the product of volume and proportional defoliation by the appropriate coefficient. In areas where up-todate inventories are on hand, an approximation of loss can be estimated by multiplying the volume per acre by an estimate of average defoliation by the type coefficient or coefficients.

A few words of caution with respect to the use of the relationships established must be brought to the reader's attention. First, it must be remembered that the damage index has been based only on ocular estimates of defoliation. Secondly, the values of the regression coefficients may differ widely 


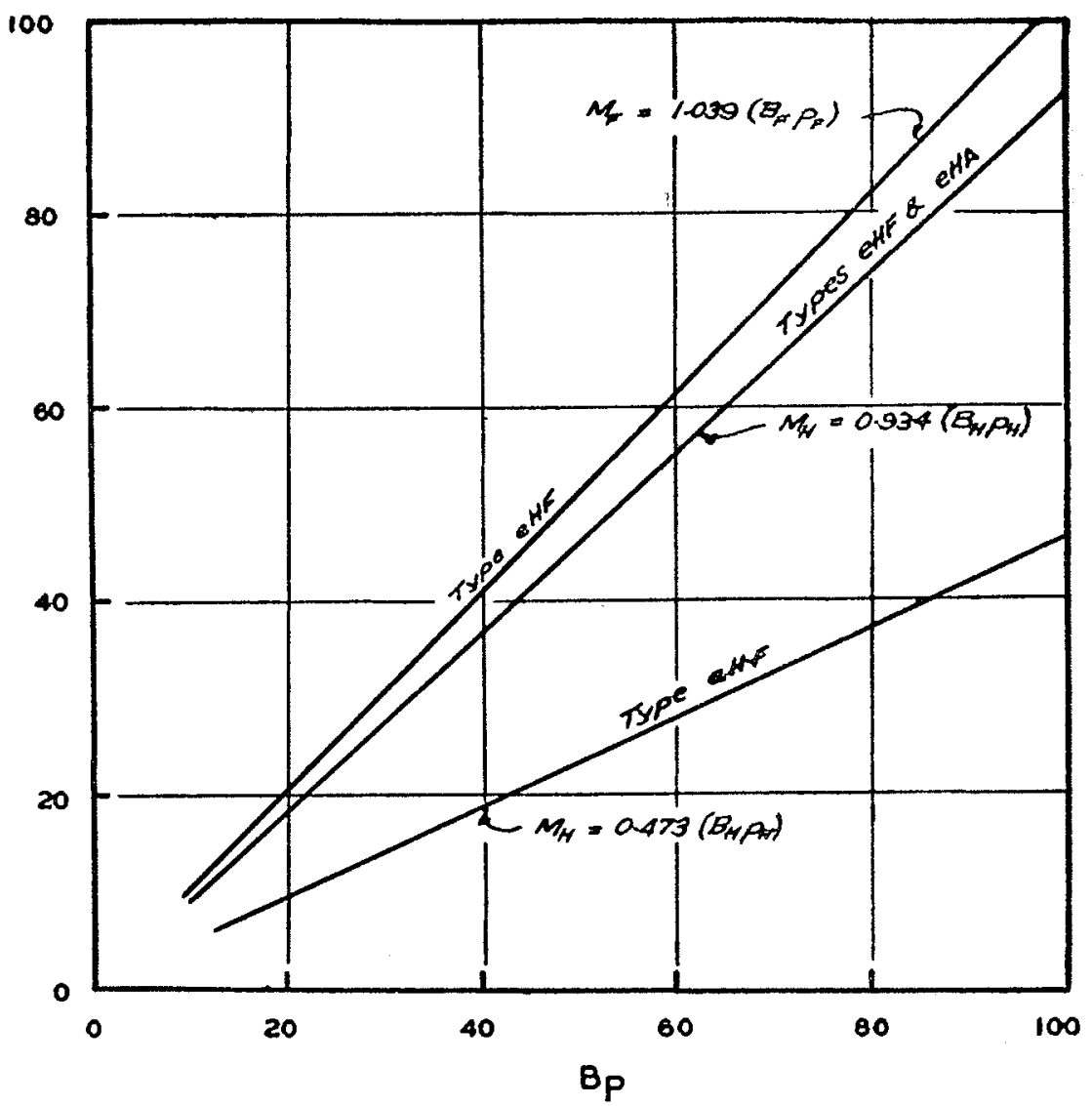

Figure 6. Graphic representation of three of the four regression relationships established by the final analysis. The dependent variable $(M)$ is the one-fifth acre plot sum of the basal area of dead trees. The independent variable (BP) is the plot sum of the products of the basal area of both living and dead trees, and the proportion of their foliage lost. The units of both axes are square feet.

from those that may pertain in forest types that are not comparable to those used for this study, and in regions of dissimilar climate. Even in the same region, deviation from the usual weather conditions may alter the fate of many trees.

Except under the duress of an extreme epidemic of some parasitic enemy, trees rarely succumb to the attack of a single organism. Death is more commonly caused by a combination of plant competition, mechanical injury, 
incipient pathogenic infections, temperature and humidity extremes and insect attack. In the case under consideration, it is probable that the death of trees completely stripped of their foliage can be attributed to hemlock looper damage alone; but the number of trees devoid of foliage in the autumn of 1946 represented a small proportion of the number of trees that were injured by this insect. On the other hand, the cause of death of these partially defoliated trees that died two to four years after the cessation of looper defoliation is problematical. The data gathered for this study were neither detailed enough, nor intended for accurate assessment of the cause of subsequent mortality. Nevertheless, a review of possible causal agents is in order.

Primarily, partial defoliation predisposes the trees to other agents by reducing the photosynthetic capacity to produce elaborated food reserves. The lack of foliage also exposes thin barked twigs to higher air temperatures. Pathogenic organisms that undoubtedly reduced tree vigor were dwarf mistletoe and root rot, Armillaria mellea (Vahl. ex. Fr.) Quél. Mistletoe was common only on hemlock, but evidence of Armillaria was frequently observed in the other three species. Although it has been stated that secondary bark mining insects were important in causing subsequent mortality $(5,6,7,8)$, the evidence is not strong enough to support this thesis without question. Belyea (1) has demonstrated that balsam fir defoliated by the spruce budworm in Ontario were dead before secondary attack by the balsam-fir beetle, Pityokteines sparsus Lec. If a similar situation obtained in these hemlock looper defoliated stands, the importance of secondary bark miners could be largely discounted. In the absence of critical measures, there are some indications that secondary insects may have been important. First, many of the larvae of the bark-mining Cerambycid, Tetropium velutinum that attacked hemlock initially were flooded out, and their galleries were healed over before the tree finally succumbed to later attacks. Secondly, many trees of all species recovered their full complement of foliage before they were successfully attacked by secondary insects. Trees that had been very lightly defoliated were also attacked. This was particularly noticeable in Type eHF stands where, in 1948, Dendroctonus pseudotsugae attacked many lightly damaged Douglas fir. Thirdly, trees in, or adjacent to areas of heavy kill were successfully attacked by secondary insects. In comparison, trees survived that were relatively far removed from areas of heavy kill, even though they suffered comparable defoliation. Apparently the beetle populations built up in stands that were completely stripped of foliage and attacked trees close to their breeding ground.

In this region where sub-freezing temperatures are not common, and where the valley floor forests are protected from excessive summer temperature by advection fog it is difficult to attribute mortality to winter-killing or to sunscald. In summary, therefore, it is the author's opinion that subsequent mortality of partially defoliated trees has been caused by a combination of partial defoliation, root rot and dwarf mistletoe and secondary bark mining beetles. 


\section{SUMMARY}

1. In the first year after the collapse of the hemlock looper outbreak, tree mortality was light; only trees that were totally stripped of their foliage died. During the second and third year, the mortality rate increased considerably, but by 1950 it had declined. The surviving trees appeared to have recovered from all signs of defoliation, so that the cumulative mortality up to 1950 was taken as the total suffered in the hemlock looper outbreak.

2. Three forest types based on species composition and diameter distribution have been recognized. Type aH.F is composed of all-age hemlock and even-aged Douglas fir. Even-aged hemlock associated with even-aged young growth Douglas fir characterizes Type eHF. Type eHA differs from aH.F and eHF by the absence of Douglas fir and by the presence of even-aged stands of either pure hemlock or mixed hemlock and amabilis fir.

3. From tabular analyses based on individual trees, it has been demonstrated that for all species except Douglas fir, larger trees suffered a higher percentage mortality for all defoliation classes than smaller trees. Also, mortality increased with heavier defoliation for all four species. Differences in mortality rates in crown characteristic, aspect and elevational categories, are explainable in terms of diameter or defoliation differences.

4. Equations have been established by multiple regression to show the relation of basal area mortality to stand composition and proportion defoliation. Inconclusive results were obtained for Sitka spruce stands. In Type aH.F, Douglas fir mortality was nil, and for comparable degrees of damage the hemlock suffered only one-half the mortality of types eHF and eHA hemlock.

In Types eHF and eHA, the hemlock mortality increased with the amount of hemlock per acre and with defoliation. Also, the death rate of Douglas fir in this type increased with the amount of Douglas fir and with defoliation.

Amabilis fir in Type eHA exhibited essentially the same relationship of increasing mortality with prevalence and defoliation, although a complex expression involving negative values of the individual basal area and defoliation coefficients was necessary to arrive at an accurate relationship.

\section{ACKNOWLEDGEMENTS}

It is a pleasure to acknowledge the help of the many members of the Victoria Laboratory who assisted in the collection of the field data. The origination and direction of the study are credited to Mr. H. A. Richmond, Officer-inCharge of this laboratory. The excellent co-operation of British Columbia Forest Products Limited, and MacMillan \& Bloedel Limited, has been invaluable. Appreciation is also expressed to Dr. W. G. Wellington for his helpful advice in the preparation of the manuscript, and to Professor F. X. Schumacher of Duke University, without whose assistance the statistical analysis could not have been undertaken. 


\section{REPERENCES}

1. BELYEA, R. M. Death and deterioration of balsam fir weakened by spruce budworm defoliation in Ontario. Part II. J. Forestry, $50: 729-738.1952$.

2. BRUCE, D., and F. X. SCHUMACHER. Forest mensuration. Ed. 2, 425 pp. McGrawHill, New York and London. 1942.

3. FISHER, R. A. Statistical methods for research workers. Ed. 10, 354 pp. Oliver and Boyd, Edinburgh and London, 1948.

4. FISHER, R. A. The design of experiments. Ed. 5, 242 pp. Hafner Pub. Co., New York. 1949.

5. KINGHORN, J. M. Fall notes on timber deterioration study. In Forest Insect Invert. Bi-Monthly Progress Rpt. 5(5). Can. Dept. Agric. 1949.

6. KINGHORN, J. M. Mortality of timber defoliated by the western hernlock looper, Lambdina fiscelleria var. lugubrosa Hlst. on Vancouver Island, British Columbia. ML F. thesis, Duke University, 1950.

7. RICHMOND, H. A. Deterioration of hemlock looper attacked stands. In Forest lasect Invest. Bi-monthly Progress Rpt. 4(4). 1948.

8. RICHMOND, H. A. Western hemlock looper. In Forest Insect Invest. Bi-Monthly Progress Rpt., 4(6). 1948.

9. SCHUMACHER, F. X. and R. A. CHAPMAN. Sampling methods in forestry and range management. Ed. 2, 221 pp. Bul. 7. School of Forestry. Duke Univ., Durham, N.C. 1948.

10. SNEDECOR, G. W. Statistical methods applied to experiments in agriculture and biology. Ed. 4, 485 pp. Collegiate Press, Ames, Iowa. 1946. 